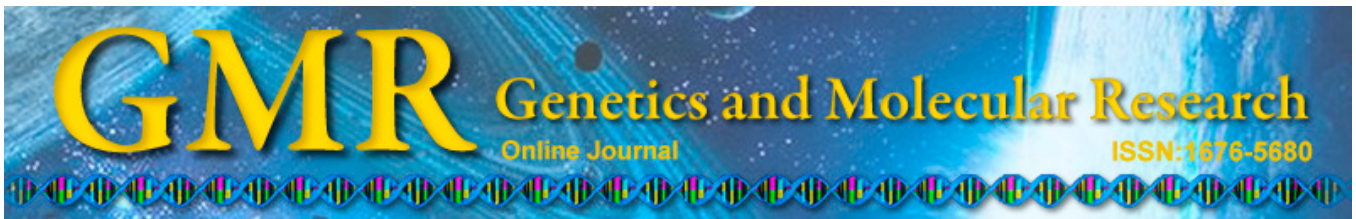

\title{
Purification of the insecticidal Cry2Ad protein from a Bt-isolated BRC-HZP10 strain and its toxin assay to the diamondback moth, Plutella xylostella (L.)
}

\author{
J.Y. Liao ${ }^{1,2,3}$, Y.Q. Gao ${ }^{1,2,3}$, Q.Y. Wu ${ }^{1,2,3}$, Y.C. Zhu ${ }^{1,2,3}$ and M.S. You ${ }^{1,2,3}$ \\ ${ }^{1}$ Institute of Applied Ecology, \\ Research Centre for Biodiversity and Eco-Safety, \\ Fujian Agriculture and Forestry University, Fuzhou, Fujian Province, China \\ ${ }^{2}$ Fujian-Taiwan Joint Centre for Ecological Control of Crop Pests, \\ Fujian Agriculture and Forestry University, Fuzhou, China \\ ${ }^{3}$ Key Laboratory of Integrated Pest Management for Fujian-Taiwan Crops, \\ Ministry of Agriculture, Fuzhou, China \\ Corresponding author: M.S. You \\ E-mail: msyou@iae.fjau.edu.cn
}

Genet. Mol. Res. 14 (3): 7661-7670 (2015)

Received September 15, 2014

Accepted April 6, 2015

Published July 13, 2015

DOI http://dx.doi.org/10.4238/2015.July.13.11

\begin{abstract}
The present study aims to characterize the Cry2Ad toxin protein isolated from a Bacillus thuringiensis strain, BRC-HZP10, which have a potential insecticidal activity against larvae of the diamondback moth, Plutella xylostella (L.). The crude Bt toxin proteins were isolated and purified by cation exchange chromatography, then equilibrated with $0.2 \mathrm{M} \mathrm{NaOH}$ buffer, $\mathrm{pH} 4.0$, followed by ultraviolet detection at $280 \mathrm{~nm}$ and sodium dodecyl sulfate-polyacrylamide gel electrophoresis. A refined Cry2Ad toxin protein with $88.34 \%$ purity was eventually obtained and used for a bioassay by feeding it to $P$. xylostella. The results showed conspicuous insecticidal activity towards P. xylostella with $50 \%$ lethal concentration of $6.84 \mu \mathrm{g} / \mathrm{mL}$ and
\end{abstract}


95\% confidence interval of 5.77-7.91 $\mu \mathrm{g} / \mathrm{mL}$. At a concentration of $16.38 \mu \mathrm{g} / \mathrm{mL}$, the intake of Cry2Ad protein significantly shortened the oviposition period and larval developmental duration, but significantly reduced the fecundity and egg hatchability of the population compared to those of control (without treatment with Cry2Ad protein) $(\mathrm{P}<0.05)$. These results indicate that the Cry2Ad protein plays an effective role in controlling the population of $P$. xylostella.

Key words: Cry2Ad toxin; Ion exchange chromatography; Purification; Sodium dodecyl sulfate-polyacrylamide gel electrophoresis;

Insecticidal activity

\section{INTRODUCTION}

Bacillus thuringiensis (Bt) was first identified by the Japanese biologist Shigetane Ishiwatari in 1901, after which thousands of strains were identified (Sanchis, 2011). The Bt $\delta$ endotoxin (Cry) protein has insecticidal activity towards many pests, and Bt-transgenic plants and -biopesticides have been developed for pest control (Saleem et al., 2010). Bt $\delta$-endotoxin is dissolved in the alkaline midgut and releases insecticidal crystal proteins after intake by insects. These activated insecticidal crystal proteins combine with a midgut epithelium-specific receptor under the effect of midgut tryptase and alter cell permeability, leading to membrane perforation, an imbalance in cell metabolism, and thus insect death (Gill et al., 1992). Because of its high toxicity, fast pathogenicity, non-toxicity to non-target insects and humans, and safety in the environment, Bt has become the most widely used microbial insecticide, playing a significant role in the biocontrol of pests in the fields (Raybould and Quemada, 2010).

Twelve Cry 2 genes have been identified: Cry2Aa, Cry2Ab, Cry2Ac, Cry2Ad, Cry2Ae, Cry2Af9 (Zhang et al., 2009), Cry2Ag (Zheng et al., 2010), Cry2Ah (Shu et al., 2013), Cry2Ai, Cry2Aj, Cry2Ak, and Cry2Al. Cry2Ad2 was officially named according to the International Commission on Bt $\delta$-Endotoxin Gene Nomenclature in 2006 (http://www.lifesci. sussex.ac.uk/home/Neil_Crickmore/Bt/index.html). The Cry2Ad2 gene segment was found to be 1919 base pairs using the primer walking method, and the length of open reading frame is 1902 base pairs, encoding for 633 amino acids. The predicted protein molecular weight is $70.72 \mathrm{kDa}$ and isoelectric point is 8.26 according to DNASTA (Feng et al., 2006; Huang, 2006).

Currently, CrylAb, CrylAc, Cry2Ab, and Cry3Aa were successfully inserted into corn, cotton, and potato plants as well as various microorganisms (Bradley et al., 1995). The fatality rate of the Cry $2 \mathrm{~A} *$ transgene towards Tryporyza incertulas reached $100 \%$ (Chen et al., 2005). High insecticidal activities were observed in the Cry2Ah1 protein generated by Cry2Ah1 expression in Escherichia coli (DE3) towards Ostrinia nubilalis (Shu et al., 2013), and Cry2Ag1 transgenic rice towards Orthoptera (Aedes aegypti) and Lepidoptera (Plutella xylostella and Heliothis armigera) (Zheng et al., 2010). This implies that the Cry2A protein has significant insecticidal activity, but few studies have examined Cry2Ad2, and insecticidal activity and effect of the Cry2Ad2 protein on P. xylostella remains unclear. Cry2Ad2 transgenic plants or microorganisms have not been produced.

In the present study, we isolated crude Bt toxin proteins from a Bt strain, BRC-HZP10, separated and purified the proteins by 732 cation exchange chromatography to obtain pure 
Cry2Ad2 proteins, and tested its biological activity towards $P$. xylostella, our results provide a strong basis for further studies on the potential application of Cry2Ad2 protein or transgenic plants expressing Cry2Ad2 to P. xylostella control.

\section{MATERIAL AND METHODS}

\section{Bt strain and insect source}

A Bt strain, BRC-HZP10, was supplied by the Key Laboratory of Biopesticide and Chemical Biology of Educational Ministry of China at Fujian Agriculture and Forestry University. The experimental population of $P$. xylostella was derived from an insecticide susceptible strain (Fuzhou-S) that was collected from a cabbage (Brassica oleracea var. capitata) field in Fuzhou $\left(26.08^{\circ} \mathrm{N}, 119.28^{\circ} \mathrm{E}\right)$ in 2004 and used for genome sequencing (You et al., 2013). This population has been reared on potted radish seedlings (Raphanus sativus) at $25^{\circ} \pm$ $1{ }^{\circ} \mathrm{C}, 65 \pm 5 \% \mathrm{RH}$ and $\mathrm{L}: \mathrm{D}=16: 8 \mathrm{~h}$ in a separate greenhouse without exposure to insecticides since 2004 .

\section{Reagents}

The sodium dodecyl sulfate-polyacrylamide gel electrophoresis (SDS-PAGE) marker was from Beijing Solarbio Technology Co., Ltd. (Beijing, China). Bovine serum albumin (purity $\geq 98 \%$ ) was from Siopharm Chemical Reagent Co., Ltd. (Shanghai, China). The SDSPAGE BC reagent was supplied by Beijing Solarbio. Other reagents were supplied by Siopharm Chemical Reagent Co., Ltd. The culture medium was prepared as described previously (Yu, 1995) and contained $10 \mathrm{~g}$ peptone, $5 \mathrm{~g}$ glucose, $2 \mathrm{~g}$ yeast cream, $2 \mathrm{~g} \mathrm{KH}_{2} \mathrm{PO}_{4}, 0.02 \mathrm{~g}$ $\mathrm{FeSO}_{4} \cdot 7 \mathrm{H}_{2} \mathrm{O}, 0.02 \mathrm{~g} \mathrm{ZnSO}_{4} \cdot 7 \mathrm{H}_{2} \mathrm{O}, 0.3 \mathrm{~g} \mathrm{MgSO}_{4} \cdot 7 \mathrm{H}_{2} \mathrm{O}$, and $0.0122 \mathrm{~g} \mathrm{MnSO}_{4} \cdot \mathrm{H}_{2} \mathrm{O}$; water was added to a volume of $1000 \mathrm{~mL}$ and the $\mathrm{pH}$ was adjusted to 7.0. The medium was solidified using $20 \%$ agar powder.

\section{Key instruments and equipment}

The TH2-C-1 desktop thermostatic shaker, SPX-250B-Z biochemical incubator, UVmini-1240-UV spectrophotometer, 5810R Eppendorf centrifuge, and DYY- 6C electrophoresis apparatus were from Beijing Liuyi Instrument Factory (Beijing, China). The electrophoresis chamber and $\Phi 15$ x $400 \mathrm{~mm}$ glass chromatographic column were from Shanghai Jiapeng Technology Co., Ltd. (Shanghai, China). The HL-2 constant flow pump was from Shanghai Huxi Instrument Factory (Shanghai, China). The BS-100 auto partial sampler and $\mathrm{pH}$ meter were from Sartorius (Goettingen, Germany).

\section{Strain cultivation and protein isolation}

The BRC-HZP10 strain was inoculated into slant culture medium for 16-18 h. We then scraped a bacterial colony and prepared the bacteria for suspension, and then inoculated the bacterial suspension into $100 \mathrm{~mL}$ liquid culture medium, cultivated the sample in a shaker at $30^{\circ} \mathrm{C}, 180 \mathrm{r} / \mathrm{min}$, for $72 \mathrm{~h}$, and finally isolated the toxin protein (Wu et al., 2004) according to previously described methods (Yu, 1995). 


\section{Purification of Cry2Ad protein by 732 cation exchange chromatography}

Treated 732 cation exchange resin was placed into the $15 \times 400 \mathrm{~mm}$ glass chromatographic column and equilibrated with $\mathrm{pH} 3.0$ buffer (prepared by mixing $11.4 \mathrm{~mL} 0.2 \mathrm{M} \mathrm{HCl}$ and $50 \mathrm{~mL} 0.2 \mathrm{M}$ glycine) (Hunter and Carta, 2001). Next, $2 \mathrm{~mL}$ crude $B t$ toxin protein was added, eluted with $0.2 \mathrm{M} \mathrm{NaOH}$ buffer, $\mathrm{pH} 12.0$, to form gradient ranging from 3.0 to 12.0, and then eluted at $2 \mathrm{~mL} / \mathrm{min}$. For each tube, sample was collected for $2 \mathrm{~min}$ using an auto partial sampler until the pH value of the eluent was 6-7. (Wang et al., 2010). The eluent was tested at $280 \mathrm{~nm}$ using a UV spectrophotometer. We desalinated and concentrated the eluent and the protein was detected using an ultra-filter tube with a cut-off value of $50 \mathrm{kDa}$. Samples were stored at $-20^{\circ} \mathrm{C}$ after freeze-drying.

\section{SDS-PAGE electrophoresis analysis}

The quality and purify of the Cry2Ad toxin protein was evaluated by SDS-PAGE electrophoresis analysis (Bradley et al., 1995). Molecular cloning guidelines for allocation of polyacrylamide gel and electrophoresis methods were according to Jin and Li (1995).

\section{Cry2Ad protein content and purity test}

Protein content was determined using a standard curve prepared based on bovine serum albumin with the Bradford Coomassie brilliant blue method (Bradford, 1976). The linear equation between protein content and absorption value was $\mathrm{y}=0.0045 \mathrm{x}-0.0071$ with a coefficient of determination of $R^{2}=0.9991$ (Figure 1). The purity of the Cry2Ad protein was $88.34 \%$.

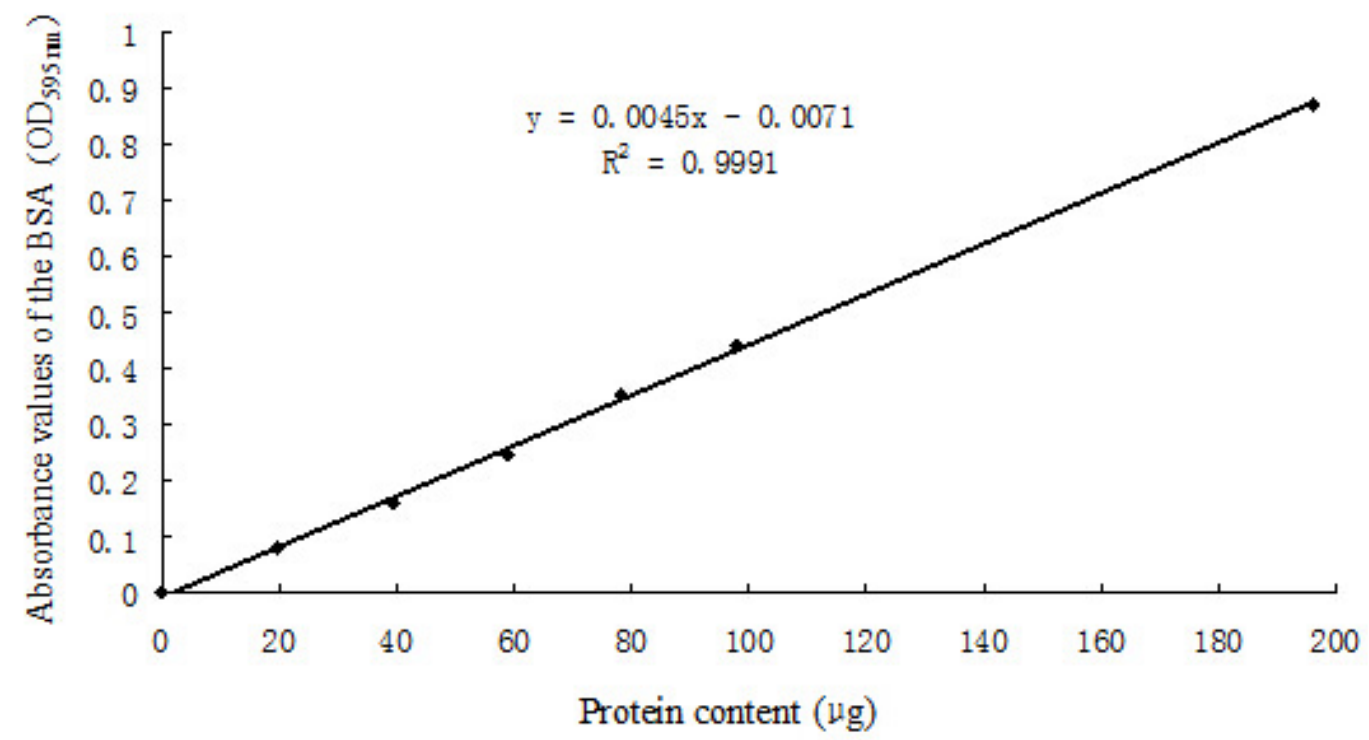

Figure 1. Standard curve of bovine serum albumin (BSA). 


\section{Toxicity test of Cry2Ad protein towards $P$. xylostella}

Fresh, untreated turnip leaves were dipped for $10 \mathrm{~s}$ into the toxin protein solution at a specific concentration. Clean filter paper was used to absorb excess solution on the leaves, which was dried and fed by the 3rd-instar larvae of $P$. xylostella after starvation for $2 \mathrm{~h}$ (Tabashnik et al., 1987; Székács and Darvas, 2013). Five gradient concentrations of the toxin protein solution were prepared, and 15 larvae were treated with each concentration; each treatment was repeated 3 times. Distilled water was used as a control group. Samples were placed into a manual growth box at $(25 \pm 1)^{\circ} \mathrm{C}$, relative humidity of $75 \pm 2 \%$, with illumination at $14 \mathrm{~h}$ (light): $10 \mathrm{~h}$ (dark). Death of P. xylostella larvae was evaluated after 72 h. The toxicity regression line was prepared to determine the $50 \%$ lethal concentration and $95 \%$ confidence limit.

\section{Growth observation of $P$. xylostella treated with Cry2Ad protein}

The 3rd-instar larvae of P. xylostella susceptible strain (Fuzhou-S) were treated with Cry2Ad protein at a $75 \%$ lethal concentration $(16.38 \mathrm{mg} / \mathrm{mL}$ based on the toxicity curve). Sixty larvae were used each treatment, which was repeated 3 times. Distilled water was used as a control group. Surviving P. xylostella were raised until pupation; pupae were collected and placed into individual tubes, the eclosion rate was calculated, and female-male ratio when pupa began eclosion was determined. After eclosion, imagoes were transferred into a culture dish at a 1:1 female to male ratio, and the imagoes were fed $10 \%$ honey water. The fecundity of each female imago was counted; 1st-instar larvae were incubated with Cry2Ad protein-treated $P$. xylostella and placed on radish sprouts at 45 insects per group, and including 3 groups. The growth and development status was observed daily. Growth duration of every instar larvae was also recorded. Plutella xylostella were placed into a manual growth box at $25^{\circ} \pm 1{ }^{\circ} \mathrm{C}$ with a relative humidity of $75 \pm 2 \%$ and illumination for $14 \mathrm{~h}$ (light): $10 \mathrm{~h}$ (dark).

\section{RESULTS AND DISCUSSION}

\section{Protein purification by cation exchange chromatography}

Protein was purified using 732 cation exchange chromatography, eluted with $\mathrm{pH}$ 12.0 buffer at $2 \mathrm{~mL} / \mathrm{min}$, collected into each tube for $2 \mathrm{~min}$, for a total of 70 tubes of eluate. Optical density at $280 \mathrm{~nm}$ was tested for each tube using a UV spectrophotometer, and the results are shown in Figure 2. The 28th tube showed the highest optical density value at $280 \mathrm{~nm}$ (marked as a), and the 43rd tube (marked as b) and the 47th tube (marked as c), which included protein eluate, were concentrated using an ultra-filtration tube with a cutoff value of $50 \mathrm{kDa}$. The sample was subjected to SDS-PAGE, and the results are shown in Figure 3. Crude separated BRC-HZP10 strain solution primarily contained proteins whose molecular weights were approximately 130 and $70 \mathrm{kDa}$. Proteins with molecular weight of approximately $130 \mathrm{kDa}$ were separated and then followed by target protein---Cry2Ad crystal protein, with a molecular weight of approximately $70 \mathrm{kDa}$. Thus, cation exchange resin chromatography can be used to separate 2 crystal proteins in the BRC-HZP10 strain. 


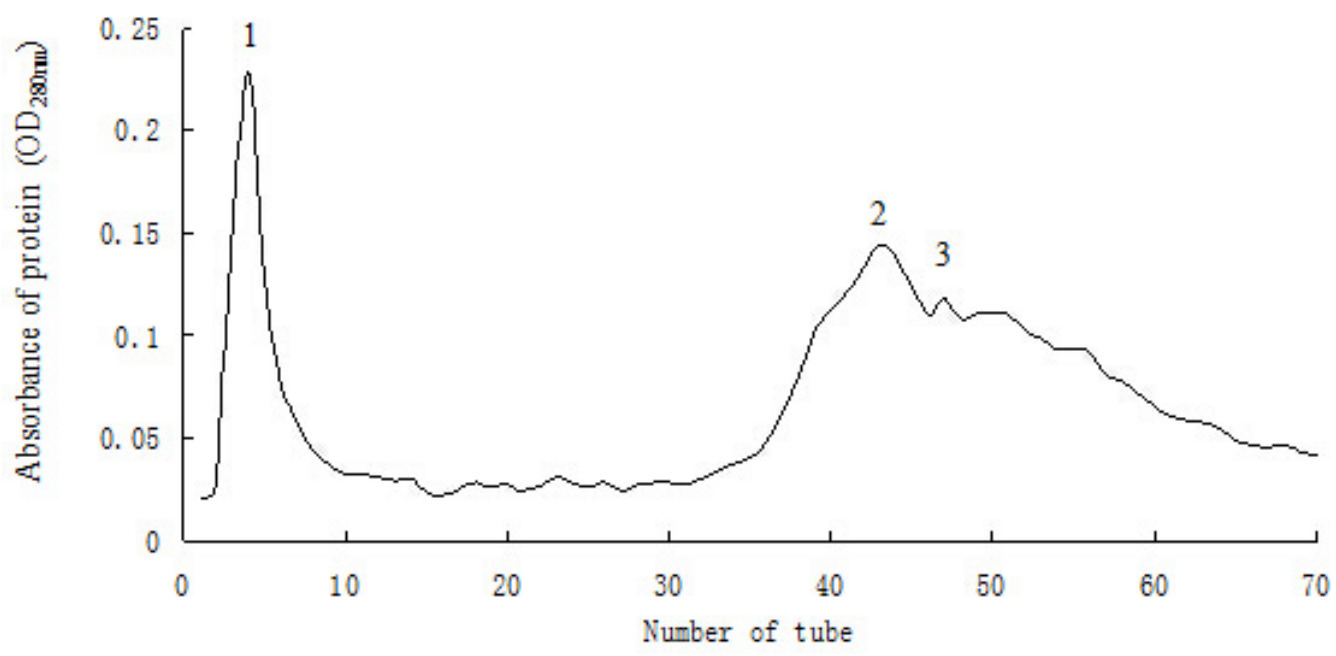

Figure 2. $\mathrm{OD}_{280 \mathrm{~nm}}$ of each eluate purified with 732 cation exchange chromatography.

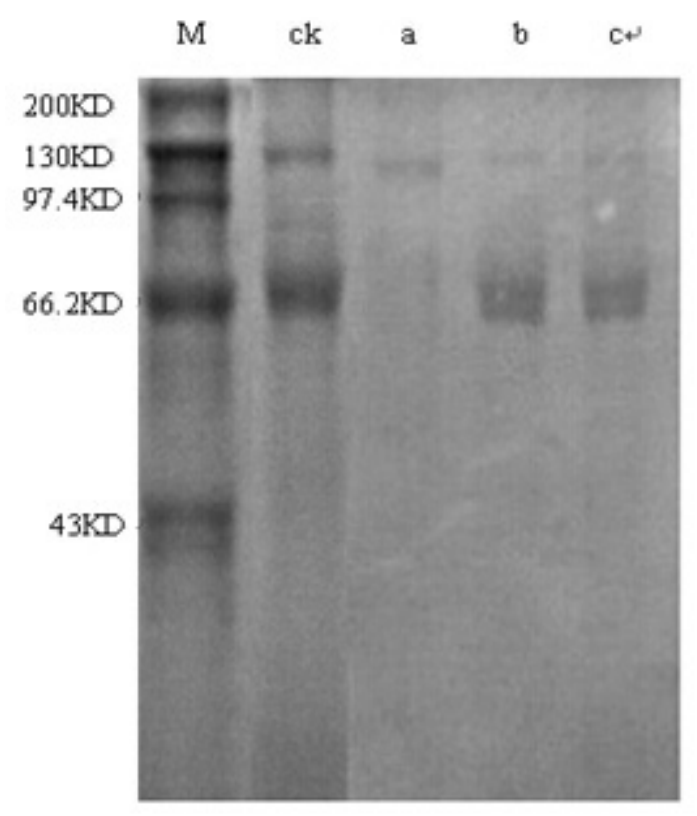

Figure 3. Electrophoresis pattern of SDS PAGE of proteins.

Excessive use of pesticides has caused many problems to the ecological environment as well as agricultural exports; therefore, Bt preparations have been successfully applied as microbial insecticides, accounting for more than $90 \%$ of the biological pesticide market. However, the quality criterion and the stability studies of active ingredients are limiting in their use. The active ingredients expressed by strains of Bt pesticide and transgenic plants differ by spe- 
cies (Székács and Darvas, 2013), and purification of the Cry protein can facilitate determination of the content of active ingredients. The $B$. thuringiensis strain used in this study contains 2 main Bt proteins with large differences in molecular weights. The cation exchange resin used in the experiment can separate and purify the Cry2Ad protein (purity reached $88.34 \%$ ) to obtain a single Cry2Ad protein used for pest control.

\section{Toxicity of Cry2Ad protein to P. xylostella}

A toxicity regression line was developed using the data from SPSS-based statistical analysis, taking the $\operatorname{logarithm}$ of the concentration $\log \mathrm{C}$ as the $\mathrm{X}$-axis and corrected mortality probability as the Y-axis (Figure 4) and resulting in the toxicity regression equation $\mathrm{y}=$ $1.7786 \mathrm{x}+3.5147$ with a coefficient of determination $\mathrm{R}^{2}=0.9969,50 \%$ lethal concentration of $6.84 \mu \mathrm{g} / \mathrm{mL}$ and $95 \%$ confidence interval of 5.77-7.91 $\mu \mathrm{g} / \mathrm{mL}$. Although the Cry2Ad protein shows higher insecticidal activity, few studies have examined this protein relative to other Cry2 proteins. Zhang et al. (2009) found that Cry2Ad has a $18.4 \%$ inhibition rate of body weight at a concentration of $100 \mu \mathrm{g} / \mathrm{mL}$ towards $P$. xylostella when studying the activity of Cry2Ad protein generated from the Cry2Ad gene expressed in E. coli Rosetta. In this study, the mortality of P. xylostella caused by Cry2Ad protein from the BRC-HZP10 strain was $77.8 \%$ at a concentration of $18.344 \mu \mathrm{g} / \mathrm{mL}$, which may result from higher purity of Cry2Ad after purification (Table 1).

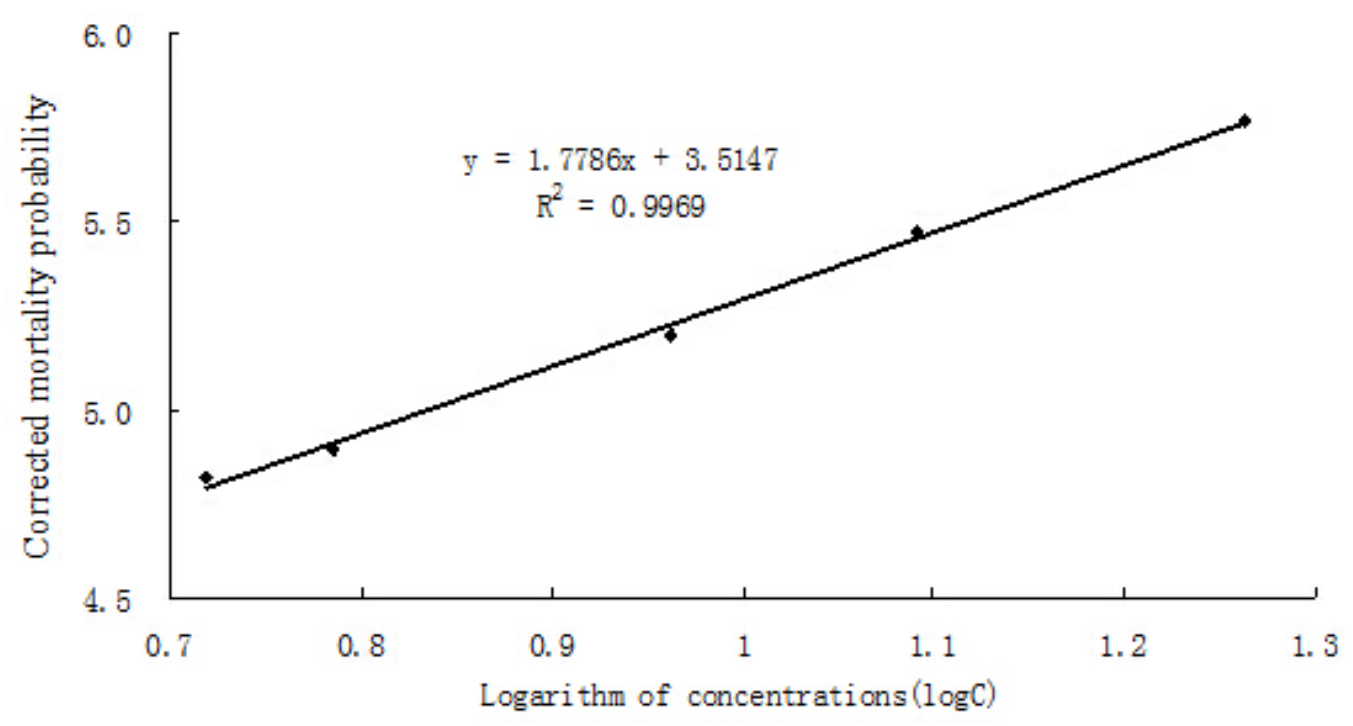

Figure 4. Toxicity regression line of Cry2Ad toxin towards Plutella xylostella.

\section{Variation in biological fitness of $P$. xylostella treated with Cry2Ad protein}

The 3rd-instar larvae of P. xylostella were fed with $16.38 \mathrm{mg} / \mathrm{mL}$ Cry2Ad protein, and the survivors were kept until pupation for examination of eclosion rate, sex ratio of female to male adults, duration of oviposition, number of eggs laid, hatching rate of eggs, and stage- 
J.Y. Liao et al.

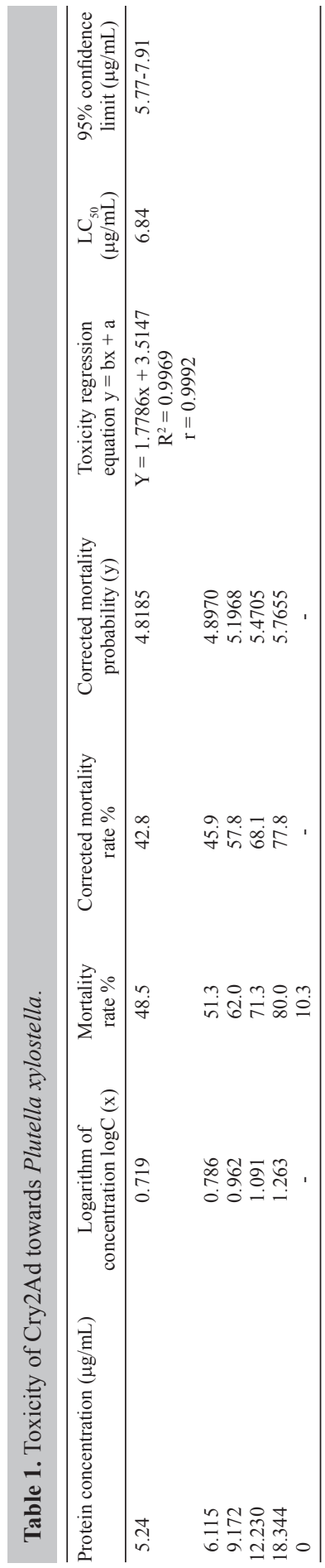


specific duration of larvae (Tables 2 and 3). The developmental time clearly indicated that intake of Cry2Ad protein significantly shortened the durations of oviposition and larval development, which may increase the generational number of $P$. xylostella. However, the fecundity and egg hatchability was significantly decreased, which may have reduced the population of $P$. xylostella. Cry2Ad protein has strong insecticidal activity towards P. xylostella; even though it might not directly lead to death. The fecundity and egg hatchability of the population were affected, indicating that this protein can be used as a potential agent to control P. xylostella. de Castro et al. (2013) found that the fecundity decreased slightly, while the duration of oviposition significantly shortened at a Cry $1 \mathrm{Ia} 12$ concentration of $0.006 \mathrm{mg} / \mathrm{mL}$ in the study on effect of the Bt suspending agent and Cry1 Ia12 on the non-target insects, Euseius concordis and Neoseiulus californicus, which was consistent with results in this study. Chen et al. (2012) found that CrylAb transgenic rice KMD2 can extend the pupal duration of Nilaparvata lugens, decrease the number of eggs laid on each of rice tillerings, and significantly reduce fecundity. There have been no studies regarding the effect of Cry2Ad protein on the biological fitness of insects, so understanding the effect of Cry2Ad protein on fecundity and egg hatchability of the population is important for the potential application of Cry2Ad protein in the development of strategies for P. xylostella control.

Table 2. Development time of Plutella xylostella treated with Cry2Ad protein.

\begin{tabular}{|c|c|c|c|c|c|c|c|}
\hline \multirow[t]{2}{*}{ Treatment } & \multirow{2}{*}{$\begin{array}{l}\text { Pupal duration } \\
\quad \text { (day) } \pm \mathrm{SE}\end{array}$} & \multirow{2}{*}{$\begin{array}{l}\text { Oviposition duration } \\
\qquad \text { (day) } \pm \mathrm{SE}\end{array}$} & \multicolumn{5}{|c|}{ Development time of larvae (day) $\pm \mathrm{SE}$} \\
\hline & & & 1st instar & 2nd instar & 3rd instar & 4th instar & Total \\
\hline Feed with Cry2Ad protein & $3.41 \pm 0.11^{\mathrm{a}}$ & $3.11 \pm 0.11^{\mathrm{bA}}$ & $5.50 \pm 0.21^{\mathrm{a}}$ & $3.37 \pm 0.07^{\mathrm{a}}$ & $2.14 \pm 0.04^{\mathrm{a}}$ & $1.29 \pm 0.05^{\mathrm{a}}$ & $12.31 \pm 0.15^{\mathrm{bA}}$ \\
\hline Control group & $3.49 \pm 0.39^{\mathrm{a}}$ & $3.67 \pm 0.09^{\mathrm{aA}}$ & $5.74 \pm 0.07^{\mathrm{a}}$ & $3.40 \pm 0.08^{\mathrm{a}}$ & $2.31 \pm 0.04^{\mathrm{a}}$ & $1.51 \pm 0.03^{\mathrm{a}}$ & $12.96 \pm 0.17^{\mathrm{aA}}$ \\
\hline
\end{tabular}

Table 3. Biological characteristics of Plutella xylostella treated with Cry2Ad protein.

\begin{tabular}{lcccc}
\hline Treatment & $\begin{array}{c}\text { Eclosion rate } \\
(\% \pm \mathrm{SE})\end{array}$ & $\begin{array}{c}\text { Female-male } \\
\text { ratio } \pm \mathrm{SE}\end{array}$ & $\begin{array}{c}\text { Fecundity amount } \\
(\text { per female }) \pm \mathrm{SE}\end{array}$ & $\begin{array}{c}\text { Egg hatchability } \\
(\% \pm \mathrm{SE})\end{array}$ \\
\hline Feed with Cry2Ad protein & $69.06 \pm 5.61^{\mathrm{a}}$ & $0.63 \pm 0.26^{\mathrm{a}}$ & $145 \pm 1.15^{\mathrm{bB}}$ & $84.22 \pm 0.49^{\mathrm{bB}}$ \\
Control group & $83.31 \pm 3.27^{\mathrm{a}}$ & $1.52 \pm 0.62^{\mathrm{a}}$ & $206 \pm 1.44^{\mathrm{aA}}$ & $92.66 \pm 0.97^{\mathrm{aA}}$ \\
\hline
\end{tabular}

The same superscript lower (or upper) case letter following the numbers between rows of a given column indicates no significant difference between the treatment and control at $\mathrm{P}>0.05$ (or $\mathrm{P}>0.01$ ).

\section{Conflicts of interest}

The authors declare no conflict of interest.

\section{ACKNOWLEDGMENTS}

Research supported through project grants (\#31230061 and \#31320103922) from the National Natural Science Foundation of China to M.S. You.

\section{REFERENCES}

Bradford MM (1976). A rapid and sensitive method for the quantitation of microgram quantities of protein utilizing the principle of protein-dye binding. Anal. Biochem. 72: 248-254. 
Bradley D, Harkey MA, Kim MK, Biever KD, et al. (1995). The insecticidal crylB crystal protein of Bacillus thuringiensis ssp. churingiensis dual specificity to coleopteran and lepidopteran larvae. J. Invertebr. Pathol. 65: 162-173.

Chen H, Tang W, Xu C, Li X, et al. (2005). Transgenic indica rice plants harboring a synthetic cry $2 \mathrm{~A}^{*}$ gene of Bacillus thuringiensis exhibit enhanced resistance against lepidopteran rice pests. Theor. Appl. Genet. 111: 1330-1337.

Chen Y, Tian JC, Wang W, Fang Q, et al. (2012). Bt rice expressing Cry1 Ab does not stimulate an outbreak of its nontarget herbivore, Nilaparvata lugens. Transgenic Res. 21: 279-291.

de Castro TR, Ausique JJ, Nunes DH, Ibanhes FH, et al. (2013). Risk assessment of Cry toxins of Bacillus thuringiensis on the predatory mites Euseius concordis and Neoseiulus californicus (Acari: Phytoseiidae). Exp. Appl. Acarol. 59: 421-433.

Feng JA, Li LM and Xing Z (2006). Cloning and characteristic analysis of cry2Ad2 gene from Novel Strain S249 of Bacillus thuringiensis. J. Northwest Sci-Tech. Univ. Agric. For. (Nat. Sci. Edn.) 34: 93-96.

Gill SS, Cowles EA and Pietrantonio PV (1992). The mode of action of Bacillus thuringiensis endotoxins. Annu. Rev. Entomol. 37: 615-636.

Huang TP (2006). Characterization of important functional genes from Bacillus thuringiensis. Doctoral thesis of Fujian Agriculture and Forestry University, Fujian Province, China.

Hunter AK and Carta G (2001). Protein adsorption on novel acrylamido-based polymeric ion-exchangers. III. Salt concentration effects and elution behavior. J. Chromatogr. A 930: 79-93.

Jin DY and Li MF (1995). Molecular cloning. Science Press, Beijing, China, 880-886.

Raybould A and Quemada H (2010). Bt crops and food security in developing countries: realised benefits, sustainable use and lowering barriers to adoption. Food Sec. 2: 247-259.

Saleem F and Shakoori AR (2010). Characterization of cry2A-type gene(s) from Pakistani isolates of Bacillus thuringiensis toxic to Lepidopteran and Dipteran insects. Pak. J. Zool. 42: 181-193.

Sanchis V (2011). From microbial sprays to insect-resistant transgenic plants: history of the biospesticide Bacillus thuringiensis. Agron. Sustain. Dev. 31: 217-231.

Shu CL, Zhang JT, Chen GH, Liang G, et al. (2013). Use of a pooled clone method to isolate a novel Bacillus thuringiensis Cry2A toxin with activity against Ostrinia furnacalis. J. Invertebr. Pathol. 114: 31-33.

Székács A and Darvas B (2013). Advanced Technologies for Managing Insect Pests. Springer, Netherlands, 195-230.

Tabashnik BE, Cushing NL and Johnson MW (1987). Diamondback moth (Lepidoptera: Plutellidae) resistance to insecticides in Hawaii: intra-island variation and cross-resistance. J. Econ. Entomol. 80: 1091-1099.

Wang L, Zhou L, Qian X and Zhang Y (2010). Optimization of conditions for the separation of peptide mixtures using strong cation exchange chromatography. Chin. J. Chromatogr. 28: 368-373.

Wu ZL, Huang TP and Qiu JZ (2004). An improved method for the isolation of plasmid DNA of Bacillus thuringiensis. J. Fujian Agric. For. Univ. 33: 200-201.

You MS, Yue Z, He WY, Yang XH, et al. (2013). A heterozygous moth genome provides insights into herbivory and detoxification. Nat. Genet. 45: 220-225.

Yu ZN (1995). Production and application of Bacillus thuringiensis. Chinese Agricultural Press, Beijing, China.

Zhang JT, Shu CL, Song FP, Liu N, et al. (2009). Cloning, Expression and Insecticidal Activity of cry2Ad Gene from Bacillus thuringiensis. Biotechnol. Bull. 15: 146-150.

Zheng AP, Zhu J, Tan FR, Guan P, et al. (2010). Characterisation and expression of a novel haplotype cry2A-type gene from Bacillus thuringiensis strain JF19-2. Ann. Microbiol. 60: 129-134. 